Proc. Estonian Acad. Sci. Biol. Ecol., 2004, 53, 3, 179-193

\title{
Changes in shoreline positions on the Harilaid Peninsula, West Estonia, during the 20th century
}

\author{
Reimo Rivis \\ Institute of Ecology, Tallinn Pedagogical University, Kevade 2, 10137 Tallinn, Estonia; \\ rrreimo@tpu.ee \\ Received 12 February 2004, in revised form 31 March 2004

\begin{abstract}
As Estonia has a flat and low-lying coastal zone, climate change and associated coastal processes could strongly affect the structure and development of its coastal ecosystems. Milder winters and increased storminess would result in the destruction of coastal areas. Shoreline changes on the Harilaid Peninsula (northwestern coast of Saaremaa Island) were investigated on three study sites. Maps (topographic and aerial photographs) from different times (1900-1998) and data of direct observations (2000-2002) were used to identify changes in the shoreline contours and position. Analysis of shoreline changes clearly show an increasing activity of shore processes over the last 20 years. Intensification of shore processes is well correlated with increased annual storminess and higher sea levels in recent decades. The diminishing of the ice cover near the coast due to warmer winters significantly enhances shore erosion, transport, and accumulation of sediments.
\end{abstract}

Key words: shoreline change, storm climatology, shore processes, landscape changes, Harilaid Peninsula, Baltic Sea.

\section{INTRODUCTION}

Changes in coastal processes (inundation, erosion, accretion, storm impact, etc.) as consequences of global climate change deserve special analysis (Bird, 1985; Leatherman \& Nicholls, 1995; Nicholls et al., 1995; Shindell et al., 2001). The anticipated sea-level rise and increased storminess (Houghton et al., 1996; Ulbrich \& Christoph, 1999) intensify coastal processes, which in turn may lead to considerable ecological change and economic damage to coastal zones.

Increasing activity of coastal processes, including beach erosion, is presumed to be associated with global climate change. Warmer winters, increased cyclonic activity, and frequent occurrence of extremely strong storms in northern Europe seem to be closely related phenomena caused by climate change. 
The heights and periods of the waves generated are governed by the wind velocity and the duration or time that the wind blows. An important factor is also the fetch, i.e. the distance over which the wind blows.

An increase in the frequency and severity of storms in coastal waters may result in the erosion of beaches that were previously stable or prograding. Beach profiles are cut back and steepened by storm waves until they attain a concave form adjusted to the augmented wave energy. A series of storms in quick succession is particularly destructive because the second and subsequent events occur on beach already reduced to a concave eroded profile (Bird, 2001).

The coastline of Estonia (ca $3800 \mathrm{~km}$ ) is strongly indented by peninsulas and bays with many islands in the coastal zone. Therefore, coastal areas form a considerable part of Estonian landscapes where the development of nature complexes proceeds on the borderline of the land and the sea. This zone may be regarded as an ecotone where exchange processes occur at high rates of intensity (Ratas et al., 1999). Coastal landscapes are diverse and rich in natural and cultural dimensions (Ratas et al., 1997). Their ecosystems comprise a large diversity of habitats and rich flora and fauna. The topography, deposits, and the regime of substance movement affect landscape structure development on coastal areas. Landscape types, especially their vegetation and overall biological diversity, are largely influenced by peculiarities of climate (Ratas et al., 1999).

Owing to their flat and low-lying morphology, many coastal areas could be affected by climate change although isostatic and tectonic land uplift would partly mitigate the effect of the anticipated sea-level rise.

The activity of coastal processes and storm impact also depend on coastal geomorphology, nearshore topography, and exposition to the waves. Specific features of the Estonian coast are as follows: (1) Estonia is rich in different geomorphic types of coasts (according to Orviku (1992): cliff shore, rocky shore, scarp shore, till shore, gravel-pebble shore, sandy shore, silty shore, and artificial shore); (2) much of the Estonian coast is experiencing isostatic and tectonic uplift ranging from 1.0 in the south-west to $2.8 \mathrm{~mm}$ per year in the north-west (Vallner et al., 1988); (3) tidal sea-level fluctuations in the Baltic Sea are negligible (ca $1 \mathrm{~cm}$ ). Short-term sea-level fluctuations near the Estonian coast are most often caused by temporal winds blowing from a single direction (prevailingly from $\mathrm{NW}, \mathrm{W}$, and SW). Maximum storm surges reaching $2.65 \mathrm{~m}$ above the Kronstadt 0 (the local benchmark for the eastern Baltic Sea) have been recorded in Pärnu Bay, whereas in the open sea the highest water level rarely exceeds $+2.0 \mathrm{~m}$.

The Harilaid Peninsula in the northwestern part of Saaremaa Island is one of the most quickly developing and best investigated coastal areas in Estonia, where vast changes in shoreline displacement and characteristics of the coastal processes were observed throughout the 20th century. The most detailed observations and measurements have been carried out during the last about 30 years (Orviku, 1974, 1988; Raukas et al., 1994; Rivis et al., 2002; Orviku et al., 2003; Kask \& Kask, 2002, 2003). 
This paper focuses on the Harilaid Peninsula. Its main objectives are (1) to find out shoreline changes in Harilaid during the 20th century; and (2) to ascertain relationships between shoreline changes (shore processes), frequency and magnitude of storms, and sea levels during stormy periods.

\section{STUDY AREA}

Harilaid is a small peninsula $\left(4.3 \mathrm{~km}^{2}\right.$ in area) on the northwestern coast of Saaremaa Island (Fig. 1). The development of the peninsula began during the latest phases of the Limnea Stage of the Baltic Sea, approximately 2000 years ago, when the highest parts of Harilaid rose above sea level (Ratas et al., 1999). Most likely there were initially two separate islands, which joined later. On the map dating back to the 17 th century Harilaid was depicted as an island. It is situated at a distance of $2 \mathrm{~km}$ from Saaremaa and is subjected to the action of strong winds and storm-waves. Today Harilaid is an elongated peninsula, with a core of NW-SE trending glacial ridge eroded by seawater. The peninsula is connected with Saaremaa Island by a 300-m-wide tombolo (Ratas et al., 1999).

The shoreline of the peninsula is $13.8 \mathrm{~km}$ long, flat and low. Harilaid borders on the Baltic Proper in the west, Uudepanga Bay in the east, and Haagi Bay in the south. The shore is covered with sandy beach ridges and coastal foredunes (up to

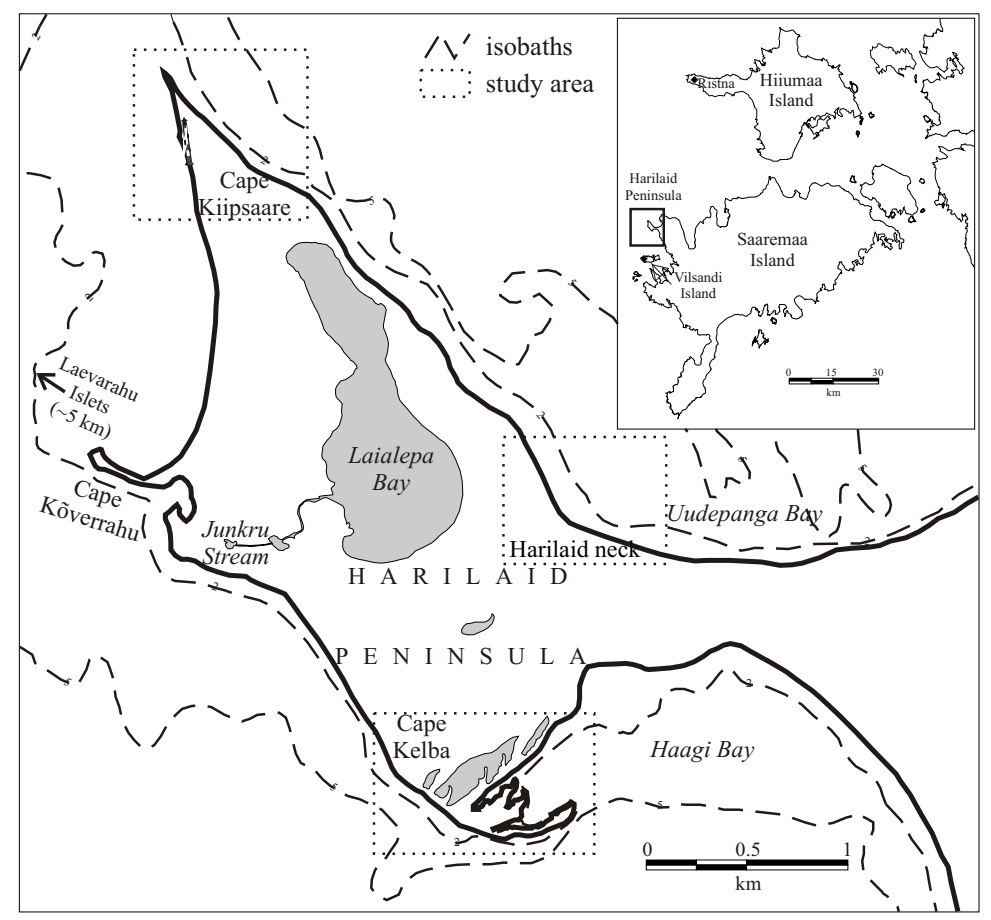

Fig. 1. Location of the study areas. 
$4.7 \mathrm{~m}$ above sea level) with sparse vegetation in the northern part and by pebbly or gravelly beach ridges and accumulation plain covered with forest in the southern part of the peninsula. There are some coastal lakes in the middle of the peninsula and a number of small bays and coastal lakes between the gravelly beach ridges in the south. The largest lake, Laialepa Bay $\left(0.64 \mathrm{~km}^{2}\right)$, divides the northern part of Harilaid into two narrow strips of land (Fig. 1). The lake is a former lagoon, which was connected to the sea via Junkru Bay (a stream now) until the Soviet frontier guard filled in the mouth of the bay.

The soils on Harilaid are young. Primitive sandy soils prevail in the northern and central parts of the peninsula; in the area of shallow depression Gleysols have developed (Ratas et al., 1999). The peninsula is of high botanical value, since a number of plant species are on the border of their distribution area here. Many rare species of vascular plants, mosses, and lichens, part of which are under protection, make this area highly valuable from scientific point of view. The protected plant species on Harilaid occur mostly in seashore communities and grasslands. The peninsula is recognized as a stopping and breeding ground for migratory birds. In the open sea near the northwestern coast of Harilaid is located an important wintering place of Steller's eider (Polysticta stelleri) (Ratas et al., 1999). Harilaid is part of Vilsandi National Park. The peninsula has always been unpopulated but its excellent beaches attract large numbers of tourists in summer.

The axis of the rhombus-shaped peninsula is oriented NW-SE, and the coastal zone is well exposed to the open sea and storm waves. A submarine sandy ridge extends from the northwesternmost point of Harilaid to NW. Currents and waves frequently modify its position. On this ridge high swell waves rise up during extreme NNW storms (Soomere, 2001). Another submarine ridge consisting of well-rounded pebble near the western coast extends $5 \mathrm{~km}$ to NW (Laevarahu and one nameless islet; Fig. 1). The sea around the peninsula is low - the 2-m isobaths lie $20-100 \mathrm{~m}$ from the shoreline and in the northwestern part approximately 500 $1000 \mathrm{~m}$ from the shoreline (Fig. 1).

Sandy shores prevail on Harilaid. Gravel-pebble shores can be found only in the southern and southwestern parts of the peninsula. Sandy beaches are usually $10-20 \mathrm{~m}$ (in places over $50 \mathrm{~m}$ ) wide. A coastal scarp borders the beach from inland. The scarp is the highest (2-3 m above sea level) in the northwestern part of the peninsula because of the greatest activity of coastal processes (particularly erosion) and the highest coastal and aeolian formations (beach ridges, foredunes) there.

The southern part of Harilaid is characterized by alternating beach ridges of well-rounded pebble. The beach ridges have been emerging at different times. The crests of some older ridges have been denudated and covered with fresh deposits, and the coastal lakes are partly filled with sediments.

Three study sites of dissimilar exposure and structure were chosen in different parts of Harilaid (Fig. 1):

1. Cape Kiipsaare - sandy beach in the northern part of Harilaid;

2. Cape Kelba - pebble and gravel beach ridges in the southern part of Harilaid;

3. Harilaid neck (tombolo) - sandy beach in the southwestern part of Uudepanga Bay. 


\section{DATA AND METHODOLOGY}

Topographic maps and aerial photographs from different times were used to identify changes in the shoreline contours and position (topographic maps from 1900, 1955, and 1988 and aerial photographs from 1955, 1981, 1995, and 1998). All maps were of the same scale $(1: 10000)$ except the oldest one from 1900 $(1: 42$ 000). Maps and aerial photographs were registered by MapInfo using control points (location of lighthouse, shorelines of lakes, crossroads, etc.) and their cartesian coordinates. Shoreline contours and the nearest inland scarp were digitized and analysed by MapInfo. The database consists of the measured variables on shoreline movements over a given (1900-2002) time interval (linear movements in metres or area changes in square metres).

Field measurements related to local benchmarks and a topographic survey of coastal formations were carried out to determine changes in shoreline positions. The measurements and the survey were repeated in the same study sites at irregular time intervals, depending on the specific tasks and the framework of different studies. Since 2001, the shoreline was fixed 2-3 times per year using GPS. Garmin 12 GPS personal navigator with maximum horizontal accuracy of $3 \mathrm{~m}$ was used. The attainable accuracy in open landscape (field, sea, coastal area, etc.) was 3-5 $\mathrm{m}$. The sea-level fluctuations during the aerial photographs and GPS measurements were up to $15-20 \mathrm{~cm}$ above or below the Kronstadt 0 . Due to the steep nearshore topography of the Harilaid Peninsula, these sea-level variations were not important. Nevertheless, the data resulting from multiple measurements provided an opportunity, in addition to qualitative assessment, to roughly estimate the amount of sediment displaced on the coast over a given time interval. Field observation records and photos taken at identical locations of the study sites during the last 35 years (Orviku et al., 2003) provide another source of data to assess shoreline displacement.

The database of long-term changes in storminess and storm climatology was made by J. Jaagus (Orviku et al., 2003). The observation date(s), highest mean wind speed, and wind directions and duration were recorded for each storm (wind speed $>15 \mathrm{~m} / \mathrm{s}$ ). Annual storminess (obtained from Vilsandi meteorological station) and annual mean sea levels (obtained from Ristna mareograph) of stormy days were used in this paper. The database of storminess includes data since 1948. Earlier data are incomplete and, therefore, insufficient for such kind of studies.

The relationships between storm data and shoreline changes were examined using a simple method of comparison. The period 1957-2001 was analysed. The shoreline changes in a given time interval were compared with the number of storm events and sea-level values over the same period, whereas the estimates are based on the storms of 2001/2002 (the baseline period of storms), whose impact on the shoreline changes was precisely measured. For other stormy periods, the number of storms with certain parameters (direction, duration, sea level) were compared (analogue storms) to the shoreline changes, which were found from maps of different times. 


\section{RESULTS}

\section{Storm climatology}

The most common indicator of storminess is the number of days with storm winds. The frequency of strong storms has significantly risen since the $1980 \mathrm{~s}$ (Fig. 2) (Rivis et al., 2002; Orviku et al., 2003). During the last 20 years annual storminess has become more frequent ( 8 more stormy days per year on average) and the mean sea levels are much higher (by $20 \mathrm{~cm}$ on average) on stormy days than $20-50$ years ago.

(a)

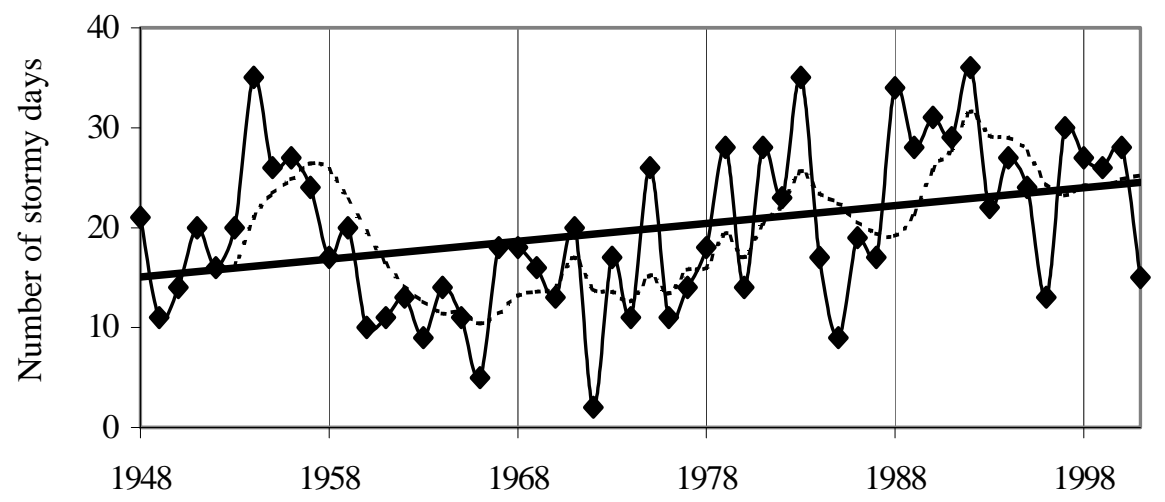

(b)

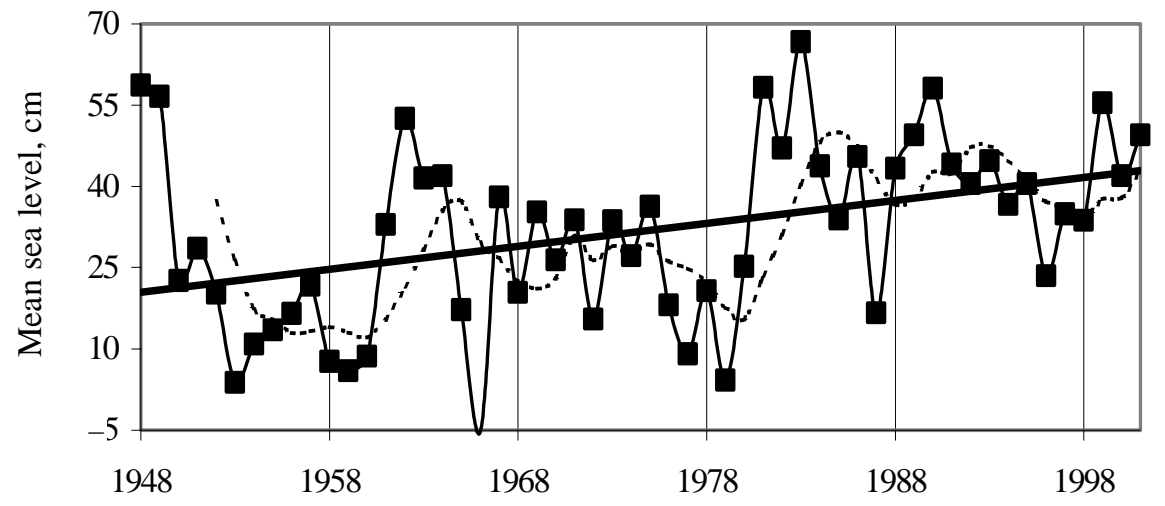

Fig. 2. Time series of storminess on Vilsandi Island (a) and mean sea level on stormy days (b) at Ristna, their 5-year moving means (dotted lines), and linear trends (bold lines) (Rivis et al., 2002; Orviku et al., 2003). 


\section{Shoreline changes}

Based on comparison of maps from different periods, shoreline changes on the Harilaid Peninsula for three areas were reconstructed (Figs. 3-5; Tables 1-3).

\section{Cape Kiipsaare}

Shore processes during the last century have caused the northwesternmost point of the peninsula to migrate to the north-east and to become longer and narrower (Fig. 3) but the area of the cape has remained almost constant $\left(\mathrm{ca} 0.2 \mathrm{~km}^{2}\right)$. In the first half of the 20th century Cape Kiipsaare migrated $30-35 \mathrm{~m}$ in the northeastern direction and during the second half of the 20th century, about 75-90 m. The western coast has receded due to erosion about $32.5 \mathrm{~m}$ during the last 7 years (Table 1). Accumulation has been generally prevailing on the eastern coast of the cape but during the last 15 years coastal erosion (the shoreline retreated ca $26 \mathrm{~m}$ ) has started even there. Similar changes have taken place also in the development

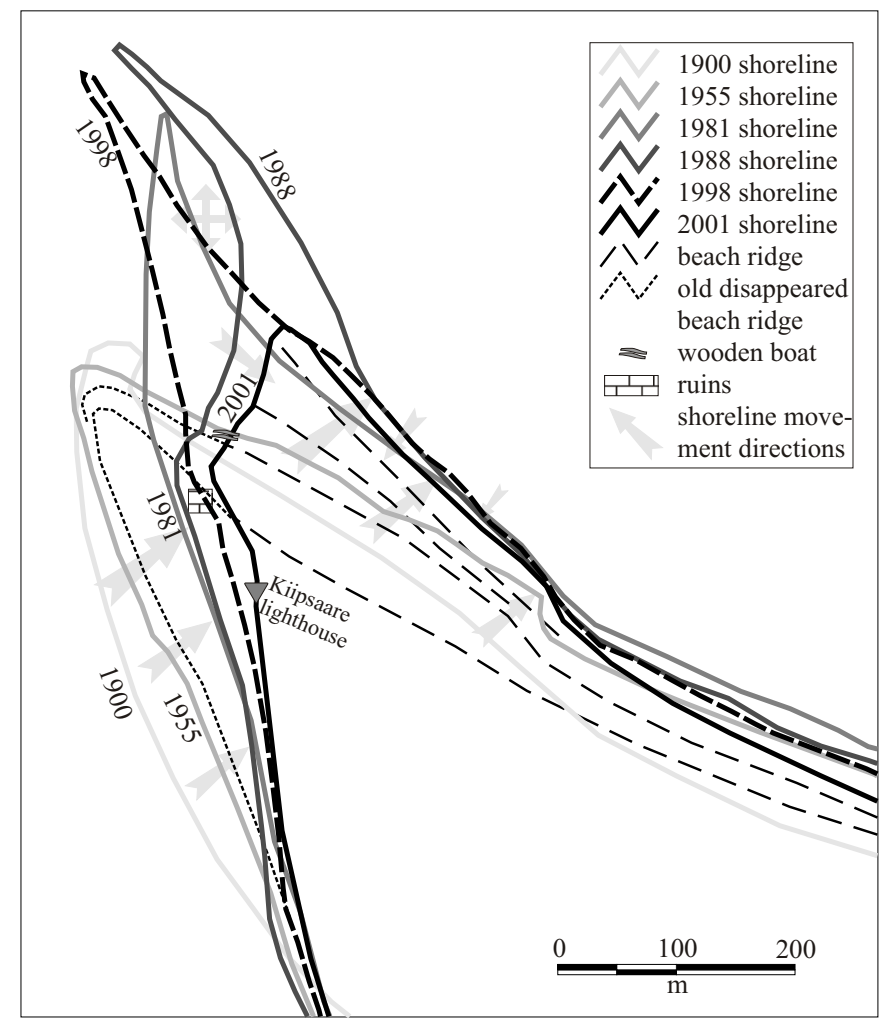

Fig. 3. Map of shoreline changes on Cape Kiipsaare. 
Table 1. Average shoreline movements on Cape Kiipsaare (- erosion, + accumulation) and number of storms analogous with the baseline period storms of 2001/2002

\begin{tabular}{r|c|c|c}
\hline Period & $\begin{array}{c}\text { Western shore, } \\
\mathrm{m}\end{array}$ & $\begin{array}{c}\text { Eastern shore, } \\
\mathrm{m}\end{array}$ & $\begin{array}{c}\text { Number of analogous } \\
\text { storms }\end{array}$ \\
\hline $1900-1955$ & -23.5 & +44 & No data \\
$1955-1981$ & -38.5 & +25.5 & 6 \\
$1981-1988$ & -8.0 & +10.0 & 1.5 \\
$1988-1995$ & -12.0 & -10.0 & 2.5 \\
$1995-1998$ & -2.5 & -1.5 & 0.5 \\
$1998-2001$ & -24 & -9.5 & 3 \\
$2001-2002$ & -6 & -5 & 1
\end{tabular}

of the scarp, which retreated up to $50 \mathrm{~m}$ from the 1950s until the 1980s, and 50$70 \mathrm{~m}$ during the last 20 years.

The greatest changes in shoreline displacement have taken place in the northwesternmost part of the study area (Fig. 3). The shoreline of this part of Cape Kiipsaare has moved back and forth $(\mathrm{ca} 100 \mathrm{~m})$ several times during the last 20 years. At the end of 2001 the shoreline of the top of this study site retreated $300 \mathrm{~m}$.

The results of the current study for the last five years on Cape Kiipsaare coincide in general with the results of the State Environmental Monitoring (Kask \& Kask, 2002, 2003).

\section{Cape Kelba}

Cape Kelba is a spit in southeastern Harilaid and consists of pebbly beach ridges. Continuous accumulation of new beach ridges is elongating the spit. Analysis of the shoreline dynamics on Cape Kelba using the maps from different times reveals an elongation and widening of the spit (Fig. 4). At the beginning of the 20th century the cape consisted of two small systems of pebbly beach ridges. There were two small coastal lakes behind the beach ridges. During the first half of the 20th century the southwestern part of the spit became wider and the area increased by $6800 \mathrm{~m}^{2}$ (Table 2). In 1955-1981 new beach ridges were formed and the increase of the area of the spit was about $18500 \mathrm{~m}^{2}$. The last 20 years saw an expansion of Cape Kelba by about $56000 \mathrm{~m}^{2}$; the rate of expansion was extremely varying from year to year.

The southwestern coast of Cape Kelba started to become eroded during the second half of the 20th century. While only approximately $900 \mathrm{~m}^{2}$ was eroded in 1955-1988, the rate of erosion increased to about $22000 \mathrm{~m}^{2}$ by the end of the century. 


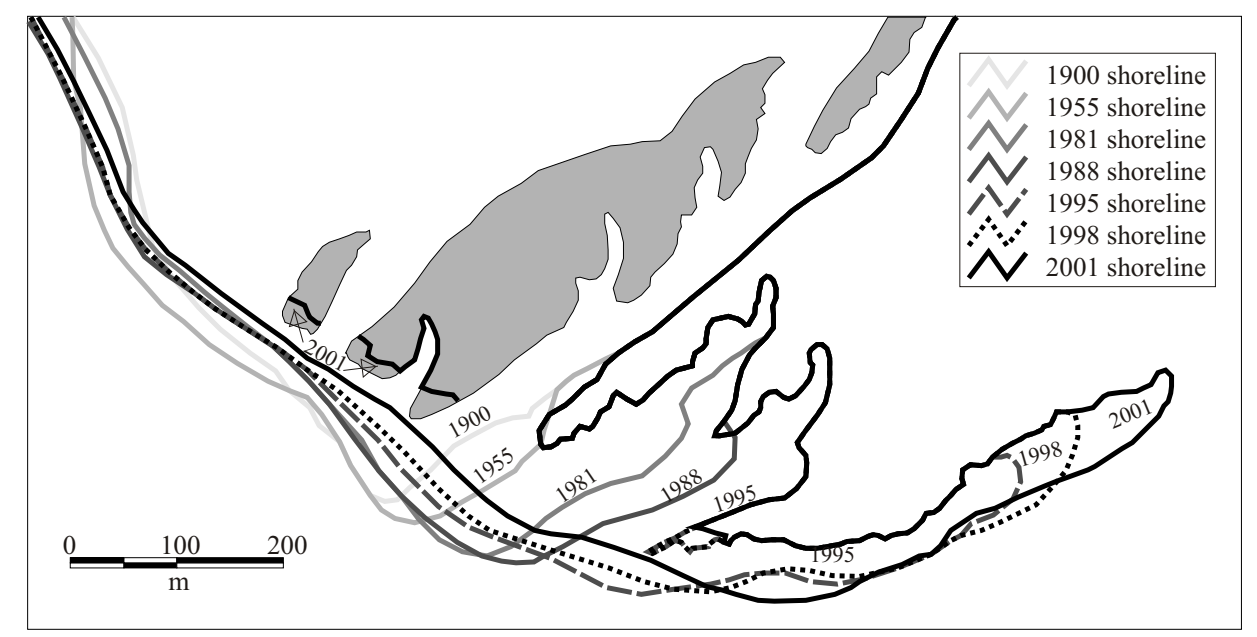

Fig. 4. Map of shoreline changes on Cape Kelba.

Table 2. Area changes on Cape Kelba and number of storms analogous with the baseline period storms of 2001/2002

\begin{tabular}{r|c|c|c}
\hline Period & $\begin{array}{c}\text { Total erosion in the } \\
\text { proximal part of the spit, } \\
\mathrm{m}^{2}\end{array}$ & $\begin{array}{c}\text { Total accumulation in the } \\
\text { distal part of the spit, } \\
\mathrm{m}^{2}\end{array}$ & $\begin{array}{c}\text { Number of analogous } \\
\text { storms }\end{array}$ \\
\hline $1900-1955$ & 0 & 6800 & No data \\
$1955-1981$ & 500 & 18500 & 5 \\
$1981-1988$ & 400 & 10500 & 3 \\
$1988-1995$ & 4300 & 28500 & 4 \\
$1995-1998$ & 4600 & 4600 & 1 \\
$1998-2001$ & 7000 & 5800 & 1.5 \\
$2001-2002$ & 6000 & 6800 & 1
\end{tabular}

\section{Harilaid neck}

The Harilaid neck (tombolo) study area on the eastern coast of the Harilaid Peninsula is a 120-m-wide accumulative plain with a sandy beach (Fig. 5). The landward half of the study area is already covered by sparse vegetation. Active shore processes, mainly sand accumulation, are taking place in the seaward half of the beach today. The sediments accumulating here come primarily from Cape Kiipsaare but also from the eastern coast of Harilaid. The rates of accumulation are higher in the central and eastern parts of the study area and lower in the north. The total displacement of the shoreline during the last century has been about $150 \mathrm{~m}$ (Table 3). The enlargement of the beach in the Harilaid tombolo study area has increased from $1 \mathrm{~m} / \mathrm{y}$ during the first half of the last century to $1.5-13 \mathrm{~m} / \mathrm{y}$ during the last 20 years. Sometimes temporary water bodies form behind shore ridges on flat sandy beaches (Fig. 5). 


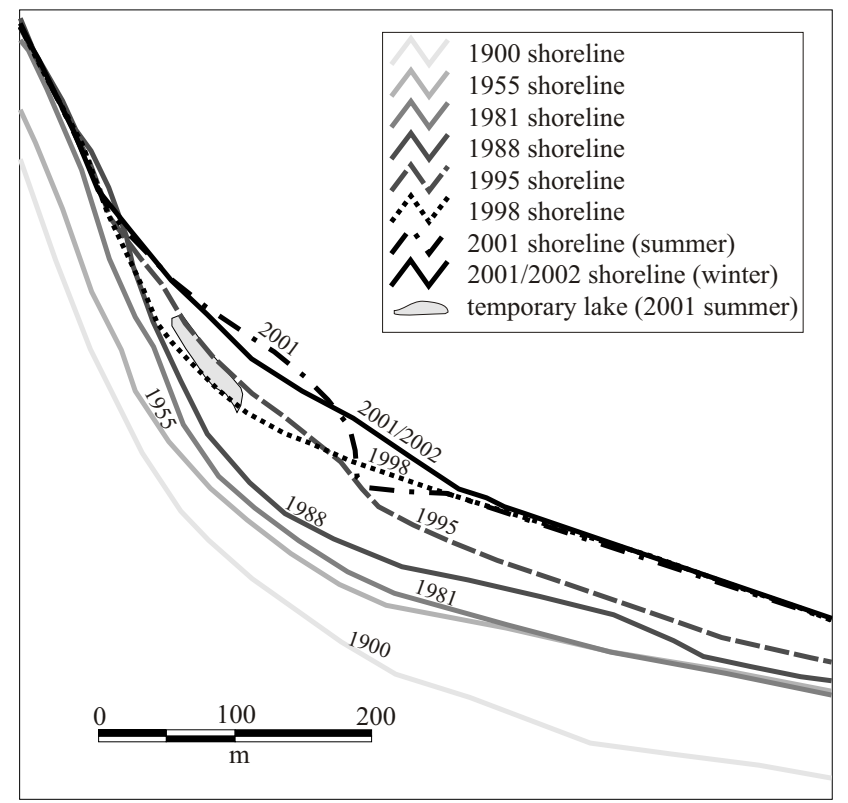

Fig. 5. Map of shoreline changes on the beach in the Harilaid neck.

Table 3. Average shoreline movements (- partial erosion) and beach increment, southwestern part of Uudepanga Bay (Harilaid neck)

\begin{tabular}{r|c|c}
\hline Period & $\begin{array}{c}\text { Shoreline movement, } \\
\mathrm{m}\end{array}$ & $\begin{array}{c}\text { Increase in area, } \\
\mathrm{m}^{2}\end{array}$ \\
\hline $1900-1955$ & 62 & 30000 \\
$1955-1981$ & 9 & 11500 \\
$1981-1988$ & 10 & 10800 \\
$1988-1995$ & 30 & 16400 \\
$1995-1998$ & $35(-12)$ & 13160 \\
$1998-2001$ & $40(-10)$ & 7650 \\
$2001-2002$ & $20(-10)$ & 2300
\end{tabular}

\section{DISCUSSION}

The changes in shoreline positions in different study areas on Harilaid are rather different. However, all these changes are more or less attributable to the increasing activity of shore processes due to frequent occurrence of extremely stormy periods and high sea levels.

Extremely strong storm winds, accompanied by higher sea level in autumn and winter, can result in even higher water level, particularly in bays. Storm winds 
typically blow from the south-west. Regression analysis shows a statistically significant $(p<0.01$ level) increase in the annual number of stormy days (Orviku et al., 2003). During the last 20 years many more stormy days per year with high sea level have been recorded than before (Fig. 2).

Warmer winters inhibit the formation of or reduce the length of the period of ice cover. The decrease in the duration of ice cover in the Baltic Sea (Haapala \& Leppäranta, 1997; Jaagus, 2003) is a clear consequence of increasing mean air temperature. Due to the most frequent occurrence of strong storms in autumn and winter seasons (Table 4), the absence of ice cover is a very significant agent influencing the shore processes (Orviku, 1993).

The shoreline changes on Cape Kiipsaare show that the shore processes have become more intensive over the last 20 years. The main reason for the migration of the cape is intense erosion on the western coast and transport of sand to the north and along the eastern coast to the south, where it is re-deposited on the northeastern and eastern coasts of Harilaid. The sediments are mainly moving within the limits of the submarine scarp (northwest of Cape Kiipsaare). This contributes to the widening of the connecting spit (tombolo) between the peninsula and Saaremaa (Orviku et al., 2003). Part of the sand eroded from the western coast of Cape Kiipsaare has been transported along the western coast to the south. At the beginning of the 1990s, a NE-SW orientated islet (Kõverrahu, Fig. 1) was connected to the peninsula by a spit made of that sand. A semi-closed bay was also formed behind the spit where seaweed was often accumulating.

Table 4. Extremely stormy periods in the West Estonian Archipelago (Orviku et al., 2003)

\begin{tabular}{c|c|c|c|l}
\hline Stormy period & $\begin{array}{c}\text { Maximum wind } \\
\text { speed, } \mathrm{m} \mathrm{s}^{-1}\end{array}$ & $\begin{array}{c}\text { Number of } \\
\text { stormy days }\end{array}$ & $\begin{array}{c}\text { Maximum sea } \\
\text { level, cm }\end{array}$ & $\begin{array}{c}\text { Prevailing wind } \\
\text { directions }\end{array}$ \\
\hline $25.11 .51-17.01 .52$ & 24 & 22 & 64 & S, SSW, SW, WSW \\
$12.08 .54-04.12 .54$ & 24 & 27 & 46 & SW, SSW, WSW \\
$18.09 .57-22.12 .57$ & 22 & 21 & 44 & NW, SW \\
$06.08 .67-29.12 .67$ & 29 & 26 & 176 & SSW, NNW \\
$17.09 .69-11.11 .69$ & 24 & 18 & 75 & N, SSW, WNW \\
$11.10 .71-29.12 .71$ & 21 & 22 & 68 & NNE, N, NNW \\
$09.10 .73-12.12 .73$ & 24 & 18 & 73 & NNW, WNW \\
$20.11 .75-31.12 .75$ & 24 & 15 & 74 & SSW, WSW, SW \\
$26.10 .80-15.01 .81$ & 28 & 24 & 95 & SW, SSW, S \\
$23.09 .83-19.01 .84$ & 22 & 42 & 111 & SW, NW \\
$07.11 .86-09.12 .86$ & 22 & 13 & 114 & WSW, SW, W, S \\
$18.09 .88-26.03 .89$ & 22 & 51 & 112 & S, SSW, SW, N \\
$26.01 .90-24.03 .90$ & 25 & 22 & 166 & SSW, SW, NW \\
$02.11 .91-13.03 .92$ & 28 & 34 & 99 & S, SSW, SW, NW \\
$28.11 .99-26.12 .99$ & 25 & 15 & 132 & SSW, SW, WSW, S \\
$01.11 .01-16.11 .01$ & 30 & 12 & 132 & SW, WNW, WSW
\end{tabular}


The reason of the migration of Cape Kiipsaare is that nowadays a coastal scarp crosses the beach ridges of different age (Fig. 3). The main shore process in the western and northern sides of the cape is erosion, as evident by a scarp formed as a result of extremely stormy periods at the end of 1999 and 2001 (15 and 12 days with storm, maximum wind speed 25 and $30 \mathrm{~m} / \mathrm{s}$, SW and $\mathrm{W}$, maximum water level $+132 \mathrm{~cm}$ ). The scarp, particularly its northwestern side, receded $25-35 \mathrm{~m}$ inland during the 2001 stormy period. The shape and position of the shoreline is most strongly influenced by westerly and northwesterly and less by northerly and southwesterly storms.

The ruins of a former military building (about $75 \mathrm{~m}$ north of the lighthouse) are below the sea level today, because sediments under the building were eroded. The ruins act partly as a breakwater, contributing also to the increasing activity of shore processes. Presumably, the further development of Cape Kiipsaare will continue in a similar way like it has been developed over the last decade: the scarp and the shoreline will recede during extremely stormy periods and the freshly formed scarps will be smoothed and flattened during the relatively silent periods between storms.

Although erosion has dominated on the western coast of Harilaid since at least the beginning of the 20th century, the correlation between shoreline changes and some storm parameters (number of stormy days, sea level, and wind direction) during the last 50 years is not very clear. The highest correlation was found between the number of storms analogous with the baseline period storms of 2001/2002 and the shoreline movements on the western coast (Table 1). The similar correlation on the eastern coast is less significant due to the replacement of the accumulation process by erosion about 15 years ago. The role of the slopes and the contour of the submarine glacial formation in wave activity is also uncertain. Likewise the role of the shoals (west of Harilaid) in the development of Cape Kiipsaare needs further investigation.

Similar development trends can be pointed out on Cape Kelba. Like on Cape Kiipsaare, the accumulated sediments in Kelba partly originated from the sea bottom (from west) and partly from the older shore ridges by longshore drift. The material deposited on new ridges is probably eroded and transported by westerly and particularly northwesterly storm surges from the submarine shoals and from old beach ridges south-west of Harilaid. Thus, the development of Cape Kelba is most strongly determined by westerly or northwesterly and less by southerly storms.

The relationships between storm parameters and coastal processes in southeastern Harilaid - Cape Kelba - are much clearer than on Cape Kiipsaare. The growth rate of the Kelba spit has increased about 8 times during the last 20 years compared to the preceding 70 years.

The results of the measurements done in the last couple of years (1999-2002) show a clear retreat of the shoreline in the proximal part of the spit due to strong erosion of the older beach ridges and lack of sediment on the submarine shoals. 
This means that the scarp retreated $20-25 \mathrm{~m}$ in $1955-1988$ and $30-60 \mathrm{~m}$ by the end of the century. During the extremely stormy period of 2001/2002 the scarp in the proximal part of the spit retreated 5-10 $\mathrm{m}$ and the western parts of the coastal lakes were filled with pebbles (Fig. 4).

The development of Cape Kelba was compared with the number of storms of different periods, which were analogous with the baseline period storms of $2001 / 2002$, and the result revealed a good correlation (Table 2). The increment of the spit during 1988-1995 does not correspond to the number of strong storms (four analogous storms) over the same period and, thus, provides an exception. According to calculations the number of analogous storms should have been at least twice as high. This is probably due to changes in the nearshore coastal topography in the area of accumulation. About 10-16 years ago the deposits were accumulated on a submarine shoal which was ca $0.5-1 \mathrm{~m}$ below the sea level. Nowadays the process of accretion is going on in much deeper (4-5 m) water. That is why the expansion of the spit in 1988-1995 was less dependent on the amount of deposits and the number of favourable storms than before and after that period.

In the nearest future Cape Kelba will probably continue increasing at the same rate as during the last decade. In case of storms from favourable directions (S, SW) the youngest formation may turn to the north (Fig. 4) like it has happened before. Northwesterly and westerly storms may cause a new increment from the southernmost point of the cape.

The Harilaid neck study area differs from the other two because all accumulated deposits here are derived from the neighbouring areas (mostly from the eastern coast of the peninsula and partly from the adjacent sea bottom). It is a classical depositional sandy beach where erosion is generally an exception. Like in other study sites, the activity of shore processes has increased here since the end of the 20th century, particularly during the last 10 years (Table 3 ).

During the stormy period of 2001/2002 the area of the central part of the beach increased about $2300 \mathrm{~m}^{2}$ and the shoreline moved 5-30 m seaward. The correlation between the stormy periods and the increase in the beach on the Harilaid neck in the southwestern part of Uudepanga Bay is not quite good.

The development of the shoreline and the increasing activity of shore processes have resulted in a considerable change in the coastal landscapes on Harilaid. The shore ridges with dunes on the scarp are covered with typical coastal dune vegetation containing many rare and protected plant species such as Elymus farctus, Lathyrus maritimus, Trifolium campestre (Ratas et al., 1999). In case of the retreat of the scarp, some plant communities (Elymus farctus) may be destroyed. Establishment of vegetation on the former lagoons is an important phenomenon in the development of coastal landscapes on Cape Kelba. The shore ridges consisting of gravel and pebble in the sites untouched by storm surges are also covered with vegetation. 


\section{CONCLUSIONS}

The correlations between storminess and shoreline changes on the Harilaid Peninsula are quite good. Analysis of the shoreline changes on the Harilaid Peninsula showed that the shore processes had become more intensive over the last 20 years. Most changes take place during stormy periods. Intensification of shore processes on the Harilaid Peninsula is well correlated with increased annual storminess and higher sea levels but also with the absence of ice cover near the coast in recent decades.

\section{ACKNOWLEDGEMENTS}

This research was funded by the Estonian Ministry of Education and Research (doctoral grant and grant No. 0282121s02) and the Estonian Science Foundation (grant No. 3772). I thank Drs. Are Kont, Urve Ratas, Kaarel Orviku, and JaanMati Punning and referees for criticism and valuable comments.

\section{REFERENCES}

Bird, E. C. F. 1985. Coastline Changes: A Global Review. John Wiley \& Sons, New York.

Bird, E. C. F. 2001. Coastal Geomorphology: An Introduction. John Wiley \& Sons, Chichester.

Haapala, J. \& Leppäranta, M. 1997. The Baltic Sea ice season and the changing climate. Boreal Environ. Res., 2, 93-108.

Houghton, J. T., Meira Filho, L. G., Callander, B. A., Harris, N., Kattenberg, A. \& Maskell, K. (eds.) 1996. Climate Change 1995. The Science of Climate Change. Intergovernmental Panel on Climate Change. Cambridge University Press.

Jaagus, J. 2003. Muutused Eesti rannikumere jääoludes 20. sajandi teisel poolel. Publicationes Instituti Geographici Universitatis Tartuensis, 93. In Uurimusi Eesti kliimast (Jaagus, J., ed.), pp. 143-152.

Kask, J. \& Kask, A. 2002. Eesti riiklik keskkonnaseire. Mererannikute seire. Aruanne 2001. aastal tehtud töödest. Part I. Manuscript. Depository of Manuscript Reports of the Geological Survey of Estonia and the Estonian Environmental Information Centre.

Kask, J. \& Kask, A. 2003. Eesti riiklik keskkonnaseire. Mererannikute seire. Aruanne 2002. aastal tehtud töödest. Part I. Manuscript. Depository of Manuscript Reports of the Geological Survey of Estonia and the Estonian Environmental Information Centre.

Leatherman, S. P. \& Nicholls, R. J. 1995. Accelerated sea-level rise and developing countries: An overview. In Accelerated Sea-level Rise and Developing Countries (Nicholls, R. J. \& Leatherman, S. P., eds.), J. Coastal Res., Special Issue, 14, 1-14.

Nicholls, R. J., Leatherman, S. P., Dennis, K. C. \& Volonte, C. R. 1995. Impacts and responses to sea-level rise: qualitative and quantitative assessments. In Accelerated Sea-level Rise and Developing Countries (Nicholls, R. J. \& Leatherman, S. P., eds.), J. Coastal Res., Special Issue, 14, 26-43.

Orviku, K. 1974. Estonian Seacoasts. Tallinn (in Russian).

Orviku, K. 1988. Some aspects of shallow water sedimentation along the Estonian coast: the Baltic Sea. In Papers Prepared for a Colloquim on Baltic Sea Marine Geology in Parainen, 1987, pp. 73-77. Espoo. 
Orviku, K. 1992. Characterization and Evolution of Estonian Seashores. Summary of doctoral thesis, University of Tartu.

Orviku, K. 1993. Nüüdisrandla. In Eesti šelfi geoloogia (Lutt, J. \& Raukas, A., eds.), pp. 29-39. Estonian Geological Society, Tallinn.

Orviku, K., Jaagus, J., Kont, A., Ratas, U. \& Rivis, R. 2003. Increasing activity of coastal processes associated with climate change in Estonia. J. Coastal Res., 19(2), 364-375.

Raukas, A., Bird, E. D. \& Orviku, K. 1994. The provenance of beaches on the Estonian islands of Hiiumaa and Saaremaa. Proc. Estonian Acad. Sci. Geol., 43, 81-92.

Ratas, U., Nilson, E., Kont, A., Puurmann, E., Kokovkin, T., Truus, L., Kannukene, L. \& Rivis, R. 1997. Insular landscape. In Small Islands of Estonia. Landscape Ecological Studies (Ratas, U. \& Nilson, E., eds.). Inst. Ecol., Publ. 5, pp. 66-130. Tallinn.

Ratas, U., Reitalu, M., Puurmann, E. \& Rivis, R. 1999. Landscape diversity as the basis for nature protection and ecotourism development on the Harilaid Peninsula (West-Estonian Archipelago). In Papers from the Department of Geography, University of Trondheim. Vol. 1. The Relevance of Research for Landscape Management - Tool or Critique (Setten, G., Semb, T. \& Torvik, R., eds.), pp. 188-198. Trondheim.

Rivis, R., Ratas, U. \& Kont, A. 2002. Some implications of coastal processes associated with climate change on Harilaid, Western Estonia. In Littoral 2002. 6th International Symposium: The Changing Coast. Proceedings. Vol. II (Gomes, F. V., Pinto, F. T. \& Neves, L. das, eds.), pp. 133-139. Porto.

Shindell, D. T., Schmidt, G. A., Miller, R. L. \& Rind, D. 2001. Northern Hemisphere winter climate response to greenhouse gas, ozone, solar, and volcanic forcing. J. Geophys. Res., 106, 7193-7210.

Soomere, T. 2001. Wave regimes and anomalies off north-western Saaremaa Island. Proc. Estonian Acad. Sci. Eng., 7, 157-173.

Ulbrich, U. \& Christoph, M. 1999. A shift of the NAO and increasing storm track activity over Europe due to anthropogenic greenhouse gas forcing. Clim. Dynam., 15, 551-559.

Vallner, L., Sildvee, H. \& Torim, A. 1988. Recent crustal movements in Estonia. J. Geodynam., 9, 215-223.

\section{Rannajoone muutused Harilaiu poolsaarel 20. sajandil}

\section{Reimo Rivis}

Harilaiu poolsaarel uuriti kolme erineva geomorfoloogilise ehitusega rannikuala: Kiipsaare nukka, Kelba maasäärt ja poolsaart Saaremaaga ühendava tombolo loodeosa liivaranda. Rannajoone muutuste uurimiseks kasutati eri aegade topograafilisi kaarte, aerofotosid (1900-1998) ning GPS-iga fikseeritud rannajoone asendeid (2000-2002). Muutusi rannajoones võrreldi tormiandmetega (kestus, tuule kiirus ja suund, meretase tormi ajal). J. Jaaguse poolt koostatud tormiandmete aegrida sisaldab andmeid viimase 50 aasta kohta. Uuringud näitavad, et sajandi teisel poolel rannajoone muutused ja rannaprotsesside aktiivsus suurenesid ning viimasel 20 aastal on muutused veelgi ulatuslikumad (erinevus varasemate perioodidega 4-8 korda). Tormiandmete analüüsil selgus, et 1970. aastate lõpust on tormipäevade arv suurenenud ning meretase tormipäevade ajal tõusnud. Lisaks eelmainitule mõjutab rannaprotsesside intensiivistumist soojadest talvedest tingitud püsiva jääkatte puudumine. 